\title{
An Analysis of Oral English Communication Problems Faced by Engineers at Workplace, Pakistan
}

\author{
Muatar Shams Memon Dr. Habibullah pathan Mahnoor Shaikh Bakhtawer Duadpota \\ Mehran University of Enginnering and Technology, Jamshoro
}

\begin{abstract}
Engineering organizations are now gradually moving towards the incorporation of innovative and persuasive strategies to augment their businesses worldwide. The significant development of the world, as a consequence of globalization has transformed the conventional strategies and requirements that were previously needed for a business to thrive. Organizations are now putting a great emphasis on the communication skills of engineers because technical skills alone are not sufficient for the engineers to perform efficiently in their respective workplaces. The reason why the facet of communication is being specifically focused on is the fact that the engineering universities and their curriculum is designed in such a way that it concentrates more on the technical skills of the students thereby neglecting their communication skills adversely. This study aims to scrutinize the various problems that the engineering graduates encounter when they are hired in their workplaces. It aims to bring forth the different communication barriers faced by the engineers in Pakistan; where the curriculum and the universities follow a conventional approach of teaching that predominantly focuses on the technical skills of these students.
\end{abstract}

Keywords: Oral communication barriers, engineering students, engineering universities, workplaces, globalization. DOI: $10.7176 /$ JLLL/74-06

Publication date: December $31^{\text {st }} 2020$

\section{INTRODUCTION}

The status of English has uplifted to a world driving vehicle of communication due to globalization. To acquire basic communication skills in professional and academic positions, individuals/ people to share their thoughts, reveal their feelings and to find a solution to their problems. Usually, people prefer to talk with each other in their local language, but they may face difficulty when they want to talk in a language that is unfamiliar to them and thinks that it is difficult for them to share their ideas and problems (Helfrich and Bosh, 2011). At workplace oral English communication and presentation skills have been identified as an important skills for engineering graduates (Aly and Islam, 2005; Darling and Dannels, 2003). The organizations are mostly depended on these skills. If these skills are not present then organizations are failed to react at the target. According to general understanding engineering graduates who have good command in English oral communication and presentation skills works efficiently at workplace.

This paper aims at investigating whether engineers of Pakistan have acquired appropriate oral English communication skill to perform efficiently at workplace.

To fulfil the aim of this paper is following objective is devised:

To examine the oral English communication problems faced by engineers at workplace.

\section{LITERATURE REVIEW}

According to Yasmin (2003), effective oral communication requires the attribute of a clear presentation which is critically important and influential for the learning process of the student. Communication is a process of expressing sharing notions, feelings and emotions, and thoughts. The communication process occurs through the exchange of messages which may be oral and non -verbal (Brooks and Health, 1993). The professionalism of an engineer does not solely lie in his technical competencies. In the contemporary world of globalization, a competency of an engineer is equally determined based on both his technical and non-technical skills. The study 'Trends in Modern Industry and Oral Presentation Barriers of Engineers of Pakistan' aims to analyse the communicative barriers that are encountered by Pakistani engineers working in their professional workplaces centered in Pakistan. The study interpreted the various barriers that are encountered by engineers during the oral representation of their skills hence affecting their performance in their workplaces negatively. Communicative skills are extremely important in any workplace, irrespective of its specialization.

\section{METHODOLOGY}

This study aims to evaluate and examine the different communication barriers that are encountered by the engineers in their respective workplaces. This paper follows a qualitative methodology to interpret the answers collected through the help of the semi-structured interviews, followed by a thematic analysis to provide a detailed analysis of all the answers by the respondents. The methodology of the paper tries to address the proposed research question with the help of a qualitative analysis of the current studies that are in relevance with the proficiency of 
English language in developing countries and how it affects the learning process of their students which later shows its implication in their respective workplaces. The main objective of the literature review is to aid in a qualitative interpretation of all the communication barriers encountered by the Engineers in Pakistan as they grapple with their presentation skills in their workplaces. This paper employs the use of both the secondary and primary resources of study to provide a detailed interpretation of the research objectives. The primary sources are the journals, articles, and other research studies that have been previously conducted on the topic similar to that of this paper to provide an empirical evidence to support the argument established in the paper. Subsequently, the paper employs the data collected through the semi-structured interviews as its secondary source to further support the thesis argument established in the paper.

\section{Data Sampling}

To address the proposed research question in a study, where it is nearly impossible for the researcher to collect data from a densely populated community or a variety of engineering institutes in Pakistan, the use of the sampling method for the purpose of collecting data has been employed to ensure feasibility (Saunders et al., 2012). For this study, a probability technique of sampling was used because the engineering graduates were selected randomly for the purpose of the semi-structured interviews. The sampling of the paper is concentrated on the employees who are currently working in K-electric as they were asked probing questions during the process of conducting the semi-structured interviews to derive the different communication barriers faced by them in their workplaces.

\section{PARTICIPANTS AND CONTEXT}

Participants in this research were Engineers of different fields at K- electric company Karachi. Participants are from category assistant manager, DM, Manager, and DGM. Thus the participants are the group of interest to researchers, the group to which researchers, would like the result of their study to be generalized. This research study context was k- electric supply company limited.

\section{Semi-structured Interview:}

The researcher began semi-structured interview data analysis based on the thematic analysis technique. This researcher then listened to the recording of interviews repeatedly and superficially followed a process of transcription to read the transcripts in detail to be able to derive relevant themes for the analysis.

\section{RESULTS AND DISCUSSIONS}

The thematic analysis is generally done in qualitative research where the research organizes and structures his observations in accordance with the prevalent or recurrent themes in the responses of the participants. They maintain that a theme should also represent some echelon of a structured meaning or response within a dataset. In light of these understandings, the researcher has derived the recurrent themes for a thematic analysis through the process of coding as illustrated above in Table 4.1. The derived themes with their respective analyses are described below:

Table 4.1:

\begin{tabular}{|c|c|c|c|c|}
\hline $\begin{array}{l}\text { Job of the } \\
\text { Respondent } \\
\text { at K-electric }\end{array}$ & Research Question & Answers by the Respondents & Codes & Themes \\
\hline $\begin{array}{l}\text { Trainee } \\
\text { Engineer }\end{array}$ & $\begin{array}{l}\text { Do you face } \\
\text { communication barriers } \\
\text { in your workplace with } \\
\text { English language? If } \\
\text { yes, then why do you } \\
\text { think you encounter this } \\
\text { issue? }\end{array}$ & $\begin{array}{l}\text { Yes, I did. Umm..I think I } \\
\text { would say that the engineering } \\
\text { school I went to never really } \\
\text { focused on our presentation } \\
\text { skills. Our curriculum was } \\
\text { mainly designed to help us } \\
\text { develop technical skills. }\end{array}$ & $\begin{array}{l}\text { Curriculum } \\
\text { Development } \\
\text { Communication } \\
\text { Barrier }\end{array}$ & $\begin{array}{l}\text { Loopholes in } \\
\text { Curriculum at } \\
\text { Engineering } \\
\text { Schools of } \\
\text { Pakistan }\end{array}$ \\
\hline $\begin{array}{ll}\text { Senior } & \text { IR } \\
\text { Officer } & \end{array}$ & $\begin{array}{l}\text { What barriers do you } \\
\text { encounter in your } \\
\text { workplace while } \\
\text { conversing in English? }\end{array}$ & $\begin{array}{l}\text { The main barrier I face every } \\
\text { day is the fear and anxiety that } \\
\text { comes along with speaking in } \\
\text { English in Pakistan. I belong to } \\
\text { Kuwait, and I have worked } \\
\text { there as well. But in Pakistan, } \\
\text { people judge you for not } \\
\text { speaking English proficiently } \\
\text { or fluently. }\end{array}$ & $\begin{array}{l}\text { Fear and } \\
\text { Anxiety } \\
\text { Social Stigmas }\end{array}$ & $\begin{array}{l}\text { Social- } \\
\text { Constructivism } \\
\text { of English } \\
\text { Language in } \\
\text { Pakistan as a } \\
\text { Post-Colonial } \\
\text { Society }\end{array}$ \\
\hline
\end{tabular}

\section{Loopholes in Curriculum at Engineering Schools of Pakistan}

The conventional education system of Pakistan follows a traditional approach to learning, irrespective of realizing the fact that every discipline has its own sets of specialization techniques that need to be taught to students. Lack of infrastructure, resources, specialized IT staff, and insufficient capital hindered Pakistan to make the knowledge 
of computer mandatory in public schools (Mumtaz, 2000). These reasons also contribute to the lack of emphasis on the oral communication skills for engineering and science students in Pakistan. The prestigious engineering schools in Pakistan are usually public and are financed by the government. Loopholes in the curriculum that is followed in engineering schools may also lead to the trait of communication apprehension (CA) which is one of the principal factors that determine the extent of a communication barrier. One of the participants who recorded his answer in the semi-structured interview said:

"We were never really made to focus on our presentation skills while we were in engineering schools. The teachers used to judge our capabilities solely on the basis of our performance in technical tasks and projects. Except two or three basic level English courses, no one taught us the importance of effective communication in workplace."

The response of this participant reflects on the ineffective curriculum that is being followed in the engineering schools of Pakistan since ages. The education advisory committee needs to realize that Pakistani students need to put in an extra effort to develop effective communication skills as English is not the first language of Pakistani citizens. A majority of households converse in their provincial languages with their family members and peers. Moreover, the engineering schools must develop a curriculum that emphasizes on the significance of communication skills for their graduates as much as they focus on developing their technical skills.

\section{Social-Constructivism of English Language in Pakistan as a Post-Colonial Society}

It is a well-established fact that learning English has become a dire need to propel forward because it is internationally understood and spoken. However, in post-colonial societies like Pakistan and India, the phenomenon surrounding the learning and acquisition of English language has also become more of a complex rather than a requirement. Nearly half of the lives of the students in these countries are wasted in learning in English while the other half are depleted in making an effort to understand the text in the course books that are predominantly in English. One of the respondents who participated in the semi-structured interviews conducted for this study was a Trainee Engineer at K-electric. When asked about his experience of communication tests that were being held during his training program at K-electric, he stated:

"I have never been to a private school. My parents could not afford the fee structure of the private schools in Pakistan as it is exorbitant....'

The response of this participant indicates that the society in Pakistan has developed a social stigma around the learning and speaking of English language. The main reason that can be traced out behind this issue is the fact that language is a post-colonial society is scrutinized to be a sign of superiority complex. People presume that having a good command over English is what makes a person smarter and more knowledgeable rather than his skills and competencies. While it is true that the ever-increasing need for effective communication skills in English language has construed a global market-oriented demand that is required for the job candidates to achieve employment in reputable companies and organization (Mehmoodzadeh, 2012), one can also not ignore the fact that it is leading to an increased socially-constructed pressure on individuals who did not have the privilege or required resources to learn the craft of English language. The social and peer-pressure of learning English that has stemmed from Pakistan's colonial history has made it more difficult to learn English instead of making it easier. This is one of the many reasons that have been stated by the respondents in their response to the questions asked in the semi-structured interviews.

\section{Fear and Anxiety}

As it has been mentioned earlier in the paper that participants feel hesitant whilst communicating in English in their workplaces, it has also been observed that they encounter fear and anxiety along with a sense of reluctance which further inhibits them from speaking efficiently. Most of the responses from the participants indicate that they lacked a sense of motivation or interest in oral communicative skills because of the milieu of their workplace and the attitude of their peers which propagates the development of these stress-inducing feelings. The participants are of the view that whenever they tried communicating in English language, their peers, colleagues, and the people surrounding them tried to let them down by making fun of their spoken English.

The major focus of engineering organizations in Pakistan tends to focus on technical skills of their employees despite the fact that oral communication skills play a significant role for engineers at workplace. Thus, there is a need to encourage the development of oral communication skills of engineering students at a professional level as well. This suggests that during their academic years, the participants or predominantly the engineers never paid significant attention to oral communication skills. It was only after joining an organization or a company that they realized the importance of oral communication abilities that could impact their productivity and work efficiency in different workplaces.

\section{CONCLUSION}

The paramount importance of oral communication skills in English cannot be ignored. Hence, the organizations must develop strategic plans and workshops that are specifically designed to help employees or engineers encountering communication barriers in their workplaces. The public administration must help the public organizations in this regard. It may provide them with the required resources to conduct workshops on developing 
communication skills. It should also develop strategies that encourage the engineers to develop an interest in the acquisition of effective communication skills instead of only focusing on their technical skills. Hence, the organizations in Pakistan must take necessary steps to develop these skills at a professional level if they were left largely unnoticed at a primary level of education in their respective employees.

\section{References}

Aly, I., M. Islam. (2005). Factors affecting oral communication apprehension among business students: An empirical study. J. Amer. Acad. Bus. 6(2) 98-103.

Brooks, W. D., \& Heath, R. W. (1993). Speech communication. Dubuque, Iowa: W.C. Brown Publishers.

Darling, A. L., D. P. Dannels. (2003). Practicing engineers talk about the importance of talk: A report on the role of oral communication in the workplace. Comm. Ed. 52(1) 1-16.

Helfrich, S. R., \& Bosh, A. J. (2011). Teaching English language learners: Strategies for Overcoming Barriers. The Educational Forum, 75(3), 260-270.

Katz, P.R. (1993), Book Reviews. Journal of the American Geriatrics Society, 41: 788-791. https://doi.org/10.1111/j.1532-5415.1993.tb07479.x

Markes, I. (2006). A review of employability skills needs in engineering. European Journal of Engineering Education, 31(6), 637-650.

Mehmoodzadeh, M. (2012). Investigating foreign language speaking anxiety within the EFL learner's interlanguage system: The case of Iranian learners. Journal of Language Teaching and Research, 3(3), 466-476.

Mumtaz, S. (2000). Factors affecting teachers' use of Information and Communications Technology: a review of the literature. Journal of Information and Technology for Teacher Education, 9 (3), pp.319-341. Retrieved November 6, 2020 from http://www.mendeley.com/research.

Schnell, L. M. (2006). Work in progress: Impacting global engineering education for new college graduates (pp. 28-31). Paper presented as ASEE/IEEE Frontiers in Education Conference. San Diego, California.

Yasmin, H. (2003). English Language Needs of Polymer Engineering Undergraduate Master in Education, Universiti Teknologi Malaysia, Skuda. 